\title{
Itaconic acid indicates cellular but not systemic immune systemy activation
}

\author{
Johannes Meiser ${ }^{1,2, *}$, Lisa Kraemer ${ }^{6, *}$, Christian Jaeger $^{2}$, Henning Madry ${ }^{3}$, Andreas \\ Link ${ }^{4}$, Philipp M. Lepper ${ }^{5}$ Karsten Hiller ${ }^{2,6,7}$ and Jochen G. Schneider ${ }^{2,4,8}$ \\ ${ }^{1}$ Cancer Research UK Beatson Institute, Glasgow, UK \\ ${ }^{2}$ University of Luxembourg, Luxembourg Centre for Systems Biomedicine, Luxembourg City, Luxembourg \\ ${ }^{3}$ Saarland University Medical Centre, Centre of Experimental Orthopaedics, Homburg, Germany \\ ${ }^{4}$ Saarland University Medical Centre, Department of Internal Medicine II, Homburg, Germany \\ ${ }^{5}$ Saarland University Medical Centre, Department of Internal Medicine V, Homburg, Germany \\ ${ }^{6}$ Braunschweig Integrated Centre of Systems Biology, Technische Universität Braunschweig, Braunschweig, Germany \\ ${ }^{7}$ Department of Computational Biology of Infection Research, Helmholtz Centre for Infection Research, Braunschweig, \\ Germany \\ ${ }^{8}$ Centre Hospitalier Emile Mayrisch, Esch, Luxembourg \\ *These authors contributed equally to this work \\ Correspondence to: Jochen G. Schneider, email: jg.schneider@outlook.com
}

Keywords: itaconic acid; metabolism; sepsis; biomarker; inflammation; Immunology

Received: February 16, $2017 \quad$ Accepted: July 27, $2018 \quad$ Published: August 14, 2018

Copyright: Meiser et al. This is an open-access article distributed under the terms of the Creative Commons Attribution License 3.0 ( CC BY 3.0), which permits unrestricted use, distribution, and reproduction in any medium, provided the original author and source are credited.

\section{ABSTRACT}

Itaconic acid is produced by mammalian leukocytes upon pro-inflammatory activation. It appears to inhibit bacterial growth and to rewire the metabolism of the host cell by inhibiting succinate dehydrogenase. Yet, it is unknown whether itaconic acid acts only intracellularly, locally in a paracrine fashion, or whether it is even secreted from the inflammatory cells at meaningful levels in peripheral blood of patients with severe inflammation or sepsis.

The aim of this study was to determine the release rate of itaconic acid from pro-inflammatory activated macrophages in vitro and to test for the abundance of itaconic acid in bodyfluids of patients suffering from acute inflammation.

We demonstrate that excretion of itaconic acid happens at a low rate and that it cannot be detected in significant amounts in plasma or urine of septic patients or in liquid from bronchial lavage of patients with pulmonary inflammation.

We conclude that itaconic acid may serve as a pro-inflammatory marker in immune cells but that it does not qualify as a biomarker in the tested body fluids.

\section{INTRODUCTION}

Recent reports have suggested itaconic acid (IA) to be a novel metabolic biomarker [1]. This suggestion is based on its intracellular identification in activated pro-inflammatory macrophages $[2,3]$ and the detection of IA in the plasma of pregnant women who developed diabetes mellitus after birth compared to controls not progressing to overt diabetes mellitus [1]. IA is a metabolic product derived from the tricarboxylic acid (TCA) cycle intermediate cis-aconitic acid, catalysed by cis-aconitate decarboxylase (IRG1/CAD). Two physiological functions of IA have been described in pro-inflammatory cells: (1) IA shows antibacterial properties by inhibiting bacterial isocitrate lyase, an enzyme of the glyoxylate shunt, giving microorganisms a survival advantage at carbohydrate limiting conditions $[2,4]$ and (2) IA inhibits succinate dehydrogenase (SDH) in the host cell to induce metabolic 
rewiring during pro-inflammatory activation $[5,6]$. Hence, IA plays a dual complementary role by triggering metabolic adaptation of the host cell and by inhibiting growth of invading pathogens. It has been reported that IA is hardly detectable in quiescent macrophages but increases to millimolar concentrations upon pro-inflammatory activation within a few hours post-activation to a maximum level at ten hours post-activation [2, 6].

It has also been reported that IA is released from proinflammatory macrophages [6-8]. These reports suggest that IA might also be detectable in the blood of patients with bacterial sepsis and thus may possibly qualify as an early biomarker in a clinical setting. However, absolute quantifications of IA are so far lacking and the potential effects of extracellular IA are unclear to date [9].

To test the hypothesis if IA might be an early sepsis marker, we quantified IA in the extracellular space of macrophages in vitro and analysed different body fluids of septic patients.

\section{RESULTS}

\section{IA release rates in vitro}

To quantify IA released from lipopolysaccharide (LPS) activated macrophages in vitro, we used the mouse macrophage cell line RAW 264.7 and murine bone marrow derived macrophages (BMDM), activated the cells with $10 \mathrm{ng} / \mathrm{ml}$ LPS and analysed the medium for the presence of IA. We determined an average extracellular concentration of $9 \mu \mathrm{M}$ for RAW 264.7 and $5 \mu \mathrm{M}$ for BMDMs, respectively (Figure 1A-1C). Given the number of viable cells we estimated an average net release rate of $2.34 \mathrm{fmol} / \mathrm{cell} / \mathrm{h}$ in the case of RAW264.7 cells and $0.53 \mathrm{fmol} / \mathrm{cell} / \mathrm{h}$ in the case of BMDMs (Table 1). The determined differences in release rates are in line with the quantified intracellular IA concentrations ( $8 \mathrm{mM}$ for RAW 264.7 cells [2] and $1.5 \mathrm{mM}$ for BMDMs, respectively (Table 1)). Assuming passive diffusion as the main driving force for extracellular IA accumulation, higher intracellular concentrations result also in higher medium concentrations after LPS stimulation.

\section{Analysis of patient derived samples}

The specific production of IA upon proinflammatory stimuli as well as the release of IA prompted us to test whether IA may potentially be measured in body fluids of septic patients or in patients with suspected progression of occult systemic bacterial infection to overt sepsis. In this case IA could represent a novel biomarker to improve to the existing clinical and laboratory portfolio for inflammation assessment.

Therefore, we analysed blood and urine samples of different sepsis patients (Table 2), bronchoalveolar lavage fluids (BALF) of patients with different lung diseases including bacterial infection or exacerbation of chronic pulmonary disease (Table 3 ).

For the analysis, we first determined the limit of quantification (LOQ) for IA in plasma with our analytical pipeline, using gas chromatography coupled to mass spectrometry (GC-MS). With $1 \mu \mathrm{M}$ (Figure 2A) the LOQ in plasma was higher compared to medium (Figure 1A) but reasonable, since the high protein content of plasma may bind a significant fraction of available metabolites, resulting in low recovery of IA. Then, we applied our analysis pipeline to screen the collected body fluids for IA. We did not detect any signal for IA in any of the body fluids, except for one single patient where we detected a low signal below the limit of quantification in the urine.
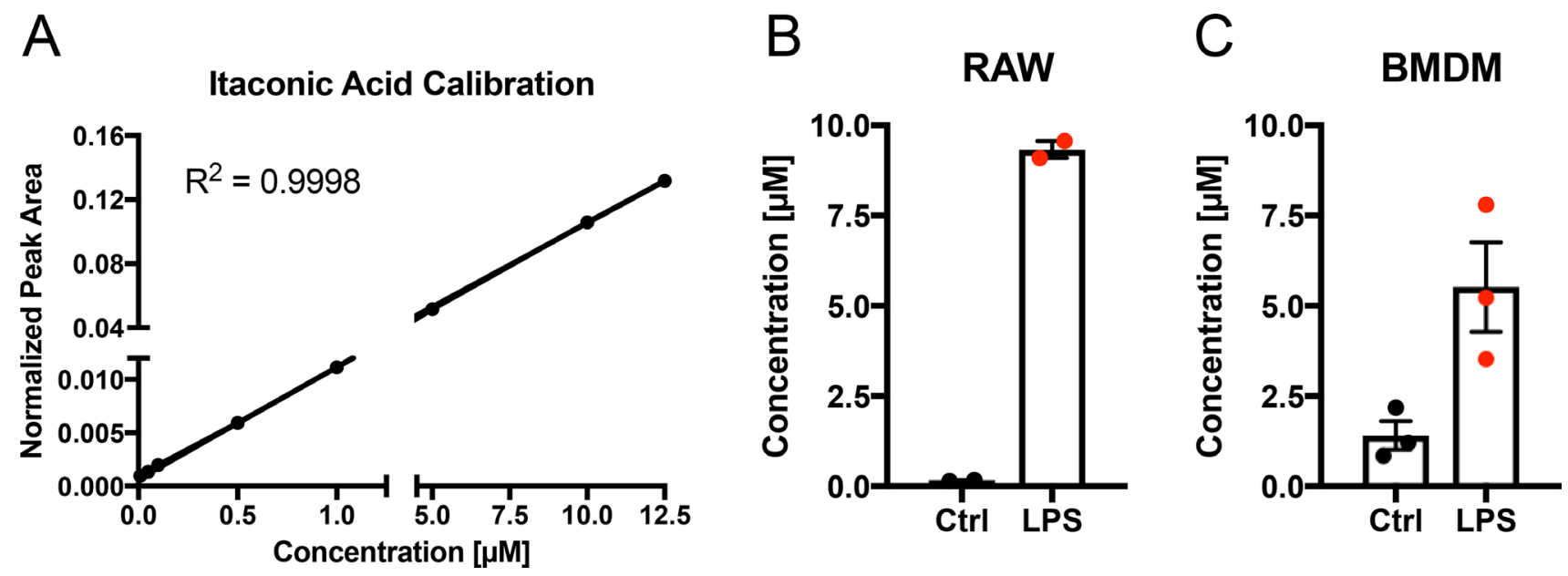

Figure 1: Quantification of itaconic acid concentration in cell culture medium upon LPS stimulation. (A) External calibration curve (concentration range: $0.01-12.5 \mu \mathrm{M}$ ) for absolute quantification of IA in cell culture medium. (B-C) IA concentration $(\mu \mathrm{M})$ in cell culture media of RAW264.7 (B) mouse macrophages and BMDMs (C) $6 \mathrm{~h}$ after stimulation (LPS) with $10 \mathrm{ng} / \mathrm{ml}$ LPS or of untreated cells (Ctrl). Each data point indicates one independent experiment with triplicate wells ( 2 experiments in (B) and three experiments in (C)). Data is represented as mean $\pm \mathrm{SEM}$. 
Table 1: Intracellular concentration of IA and release rates upon LPS activation

\begin{tabular}{lcc}
\hline & Conc [mM] & Release [fmol/cell/h] \\
\hline RAW & $8[2]$ & 2.34 \\
BMDM & 1.51 & 0.53 \\
\hline
\end{tabular}

The concentration in RAW cells is derived from [2]. Release rates were determined based on medium concentration (Figure 1), viable cells and time after LPS activation.

Table 2: Sepsis patient overview

\begin{tabular}{|c|c|c|c|c|c|c|}
\hline Gender & Age & Type of Infection & Leu & CRP & PCT & Type and duration of Therapy \\
\hline M & 60 & Unclear & 8.7 & 117 & 8.7 & Fortum and Tygacil 5th day \\
\hline M & 75 & Retention pneumonia & 14.3 & 101 & 1.6 & Tazobac, Meronem 2nd day \\
\hline M & 57 & Pancreatitis and Pneumonia & 6.8 & 390 & 16.6 & Tazobac, Tavanic 2nd day \\
\hline M & 71 & Pneumonia (repeated sepsis) & 9.4 & 133 & 1.1 & Vancomycin, Meronem 1st day \\
\hline M & 64 & Aspiration pneumonia, & 13.9 & 332 & 2.5 & Vancomycin, Meronem 1st day \\
\hline M & 57 & Endocarditis, pneumonia & 18.9 & 377 & 2.1 & $\begin{array}{l}\text { Zyvoxid, Eremfat 1st day, Clont } \\
\text { 3rd day }\end{array}$ \\
\hline M & 57 & Pneumonia & 9 & 111 & 1.1 & Tazobac, Tavanic 1st day \\
\hline M & 73 & Retention pneumonia, STEMI & 7.4 & 130 & 2.4 & Tazobac, Tavanic 2nd day \\
\hline M & 59 & $\begin{array}{c}\text { Retention pneumonia, cardiogenic } \\
\text { shock }\end{array}$ & 11 & 234 & 3.5 & Vancomycin, Meronem 1st day \\
\hline M & 57 & Pneumonia ARDS & 18.7 & 81 & 2.4 & Maxipime, Vancomycin 4th day \\
\hline M & 86 & Retention pneumonia & 17.7 & 173 & 1.4 & Vancomycin, Meronem 2nd day \\
\hline M & 66 & Urosepsis & 22 & 402 & 122 & Tazobac, Tavanic 2nd day \\
\hline M & 70 & Retention pneumonia & 19.5 & 188 & 1.3 & Vancomycin, Meronem 2nd day \\
\hline $\mathrm{F}$ & 85 & $\begin{array}{l}\text { Pneumonia (aspiration } \\
\text { pneumonia) }\end{array}$ & 7.1 & 208 & 4.8 & Tazobac, Tavanic 4th day \\
\hline M & 77 & Pneumonia, infected hematoma & 10.8 & 315 & 2.2 & Vancomycin, Meronem 2nd day \\
\hline M & 68 & Pneumonia & 14.2 & 211 & 9.1 & $\begin{array}{l}\text { Vancomycin, Meronem, Clont 2nd } \\
\text { day }\end{array}$ \\
\hline M & 66 & Aspiration pneumonia & 10.5 & 149 & 5.6 & Tazobac, Tavanic 2nd day \\
\hline M & 55 & $\begin{array}{l}\text { Retention pneumonia during } \\
\text { cardiogenic shock }\end{array}$ & 19.6 & 270 & 4.7 & Tazobac, Cubicin 2n day \\
\hline $\mathrm{F}$ & $\mathrm{N} / \mathrm{A}$ & Urosepsis & 20.9 & 201 & 262 & Vancomycin, Meronem 1st day \\
\hline
\end{tabular}

Healthy individuals served as controls. PCT: pro-calcitonin; CRP: c-reactive protein.

However, we did not detect a signal in the respective plasma sample. Interestingly, this patient was suffering from a genitourinary tract infection and urosepsis.

To cross validate our results we employed a set of commercial sepsis samples comprising four plasma and four serum samples (Table 4). Also in these samples, all values were close to, or below the detection limit (Figure 2B). As a positive control we also measured lactate concentrations, a metabolite that is known to be increased under septic conditions. As expected, both serum and plasma samples had significantly increaseed lactate concentrations compared to respective controls (Figure 2C-2E).
Intrigued by the one urine sample where we observed at least a low IA signal, we further investigated if patient derived cells contain IA and thus, locally, leukocytes might increase IA concentrations by low excretion rates. To that end, we analysed the cell pellets obtained from the bronchial lavages. In patients with severe lung infections, leukocytes migrate into the alveoli and are aspirated during the lavage. These cells were pelleted during sample processing and snap frozen. Intracellular metabolites of these pellets were extracted and analysed with GC-MS. In most of these samples we could detect low abundant signals for IA and we observed 
Table 3: Patient overview bronchial lavage samples

\begin{tabular}{lcccl}
\hline gender & Age & leucocytes $\mathbf{G} / \mathbf{L})$ & CRP $(\mathbf{m g} / \mathbf{L})$ & \multicolumn{1}{c}{ pathology } \\
\hline $\mathrm{f}$ & 56 & 11,80 & 42,30 & pulmonary abscess \\
$\mathrm{m}$ & 67 & 6,60 & 26,30 & interstitial nephritis \\
$\mathrm{m}$ & 44 & 6,40 & 9,80 & pneumonia \\
$\mathrm{m}$ & 63 & 8,30 & 3,30 & COPD \\
$\mathrm{f}$ & 44 & 14,20 & 1,70 & bronchogenic cyst \\
$\mathrm{m}$ & 54 & 24,50 & 5,60 & hemoptysis \\
$\mathrm{f}$ & 52 & 2,10 & 17,80 & adenocarcinoma \\
$\mathrm{f}$ & 27 & 8,90 & n.a. & sarcoidosis \\
$\mathrm{f}$ & 62 & 6,60 & 1,20 & adenocarcinoma \\
$\mathrm{m}$ & 77 & 6,40 & 4,50 & adenocarcinoma \\
$\mathrm{f}$ & 10,00 & 3,10 & small cell lung cancer \\
$\mathrm{m}$ & 62 & 1,04 & 32,90 & mesothelioma \\
$\mathrm{f}$ & 69 & 7,20 & 8,90 & small cell lung cancer \\
$\mathrm{f}$ & 69 & n.a. & n.a. & chronic cough \\
$\mathrm{m}$ & 69 & 7,90 & 24,00 & pneumonia \\
$\mathrm{f}$ & 74 & 7,80 & 23,10 & adenocarcinoma \\
\hline
\end{tabular}

a significant correlation $\left(R^{2}=0.39 ; p\right.$-value $\left.=0.016\right)$ with the C-reactive protein (CRP) values (Figure 3, Table 3), indicating that systemic inflammation correlates with the detected IA signals. Hence, it might be possible that locally, IA concentrations in the microenvironment are increased as a result of low excretion rates.

\section{DISCUSSION}

In this study we profiled IA release rates from macrophages in vitro and we analysed different body fluids of patients suffering from acute sepsis to test if IA might accumulate to sufficient concentrations in the circulation. The latter case would mean that IA could potentially serve as a novel biomarker in clinical settings to detect systemic bacteremia [10]. A novel metabolic biomarker detectable in the plasma could be an asset to the existing clinical and laboratory portfolio for sepsis assessment, since a precise diagnosis for acute sepsis, especially at an early stage, is still challenging [11]. Using marker metabolites in blood samples as biomarkers is of high interest due to the ease of accessibility and availability in clinical settings. A wellknown example is the oncometabolite 2-hydroxyglutarate (2HG), which can be used as a biomarker in isocitrate dehydrogenase (IDH) mutated acute myeloid leukemia (AML) and intrahepatic cholangiocarcinoma (ICC) patients $[12,13]$. Due to its rapid production upon extracellular pro-inflammatory stimuli, IA could theoretically qualify as an early biomarker, helping to identify minimal systemic inflammatory responses similar or even superior to pro-calcitonin [14]. A similar hypothesis has recently been raised in the context of rheumatoid arthritis [15].
However, we were not able to detect elevated IA levels in the analysed body fluids from septic patients. Therefore, IA does not seem to be a suitable biomarker of systemic inflammation employing standard routine laboratory methodology.

Our result is in contrast to the previous report by de Seymour et al. [1], who reported IA as a biomarker in peripheral blood of pregnant women who progressed to overt diabetes mellitus post partum. The reason for this discrepancy in detecting IA in peripheral blood remains unclear and might be at best caused by different technology being applied for detection. However, our results clearly indicate that in a clinical setting, IA is not detectable with a standard (but state-of-the-art) analytical infrastructure even in septic conditions. This observation is corroborated by the fact that there is, to our knowledge, no other report of increased IA concentrations, neither in sepsis nor other patient cohorts.

The low concentrations of IA in the circulation are supported by the very low excretion rates that we determined in our in vitro experiments. Despite high intracellular IA concentrations in the $\mathrm{mM}$ range we only observed very low release rates. As a comparison, the extracellular lactate concentration in similar experiments with RAW 264.7 cells has been reported to be $20 \mathrm{mM}$, resulting in a net release rate of $170 \mathrm{fmol} / \mathrm{cell} / \mathrm{h}$ [16], indicating that the release of IA into the extracellular space happens at a low rate.

The IA concentration in the tissue culture media might also be explained by accumulative release from apoptotic cells or by lysosomal trafficking and fusion with the plasma membrane. However, the latter mechanism 
alone is not sufficient to reach the measured concentration in our in vitro experiments, suggesting that the detected IA might be a net result of both, diffusion and release from vesicles and apoptotic cells. As an alternative to release, IA might be further metabolised within the cell although a mammalian metabolic degradation pathway for IA has so far only been described for the liver [17, 18]. To provide detailed explanation on these possibilities, further work is required in the future.

The notion that IA is mainly intracellularly abundant and not actively excreted is supported by our observation that we could not detect IA in the liquids of BALF's but in intracellular extracts of BALF derived cell pellets.

When analysing the intracellular extracts, we even observed a correlation between the measured IA signal and the determined CRP values. These data suggest that the higher IA signals originate from the intracellular space of the leukocytes associated with the increased CRP. We can speculate that this specific observation also applies to the recorded signal in the urine of the urosepsis patient where the IA signal likely derived from apoptotic leukocytes in urine.

Based on the low excretion rates, a paracrine effect in the microenvironment is still debatable. But due to its chemical properties as a charged molecule IA can hardly cross the plasma membrane, which is why in in vitro experiments extracellular IA is applied in the $\mathrm{mM}$ range to cross the plasma membrane and/or membrane permeable dimethylIA is used $[5,6]$. In terms of potential antibacterial properties in the extracellular space, IA concentrations are most probably orders of magnitude too low to inhibit bacterial growth [2]. Required concentrations in the $\mathrm{mM}$ range are most likely only possible to appear within the cells. We still cannot exclude that IA may have distinct
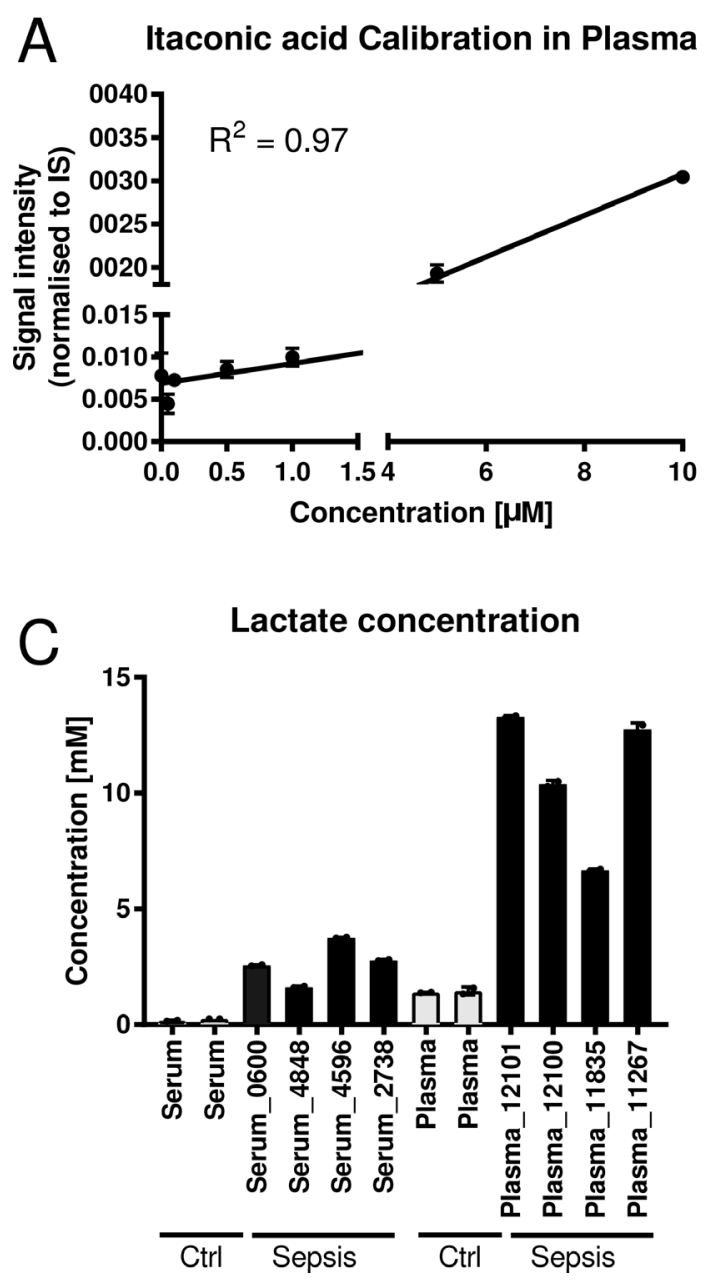
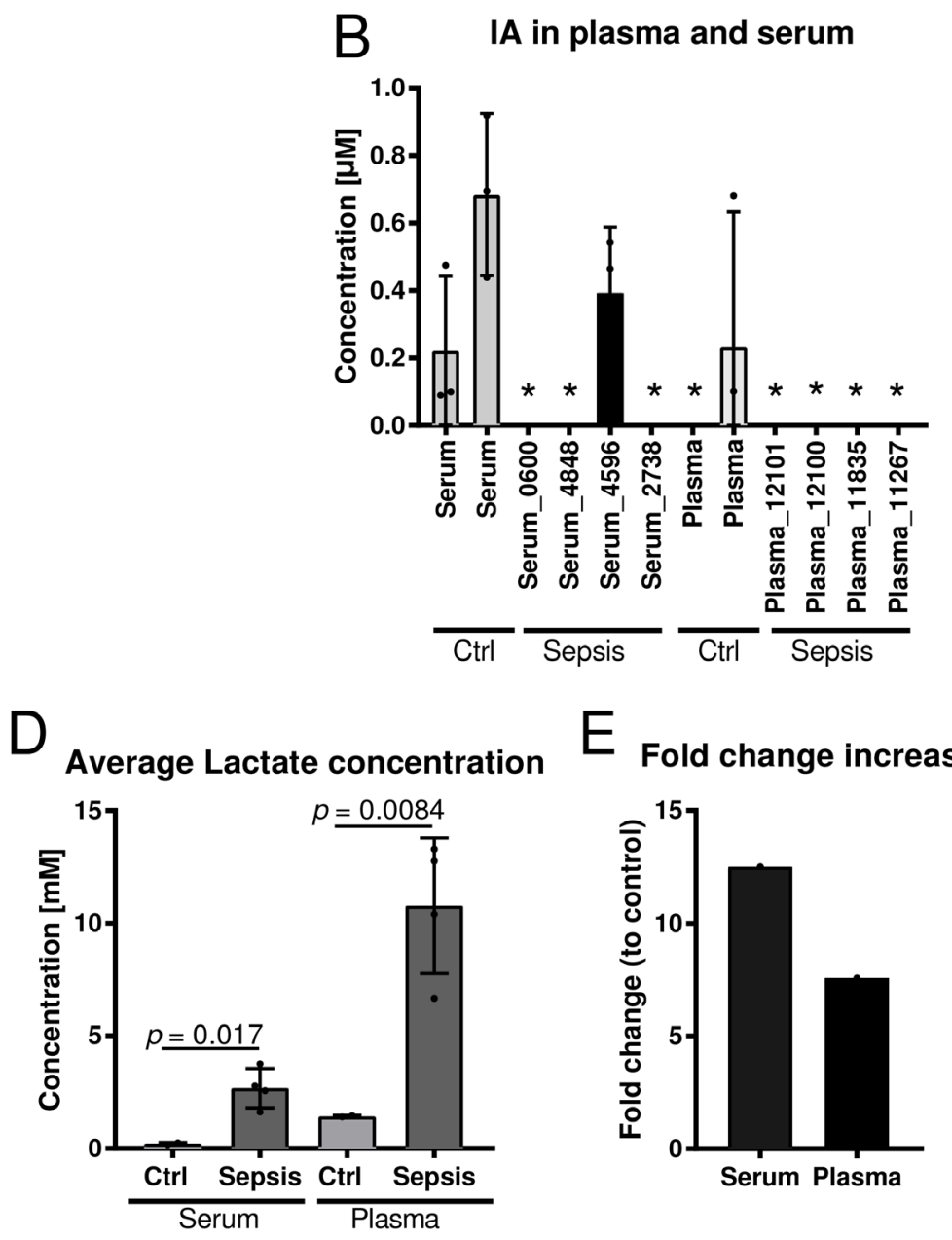

Figure 2: Quantification of itaconic acid and lactic acid in serum and plasma samples of sepsis patients. (A) External calibration curve (concentration range: $0.01-10 \mu \mathrm{M}$ ) for absolute quantification of IA in plasma and serum. (B) Quantification of IA in four plasma and four serum samples of sepsis patients with respective healthy control samples. For background subtraction the determined average IA concentration of control samples was subtracted of the determined concentrations of the sepsis samples. Each sample was analysed in three technical replicates. "indicates samples with IA concentrations below the detection limit. (C-D) Quantification of lactate in the same samples as in (B) and (E) respective fold change increase of lactate in sepsis samples compared to respective controls. Data $(\mathrm{A}-\mathrm{D})$ is represented as mean $\pm \mathrm{SD}$. 
effects involving the activation of so far unknown signalling pathways or facilitating receptor activation. An example for such a metabolite derived activation, with similar chemical structure, is given by succinate activating GPR91 to promote stem cell migration [19]. However, at this point testing such hypotheses are beyond the scope of the present manuscript. Our data support primarily the notion that IA acts as a cell intrinsic factor to inhibit SDH in the host cell and potentially, to support bacterial killing in lysosomes by inhibiting the glyoxylate shunt.

To reach a translational pre-clinical stage it will be important to evaluate if and how IRG1/CAD and IA could be exploited to treat inflammatory diseases in humans rather than serving as biomarkers.

In summary, our results indicate that IA may rather acts as a local antimicrobial metabolite. It does not represent a suitable biomarker to be used in a clinical setting.

\section{MATERIALS AND METHODS}

\section{Cell culture}

RAW 264.7 mouse leukaemic cells (ATCC ${ }^{\circledR}$ TIB-71 ${ }^{\mathrm{TM}}$ ) were cultured as described in detail in [16]. Briefly, cells were cultured in DMEM D5796 supplemented with 10\% FBS. Macrophages (BMDM) were differentiated from bone marrow of wild type mice: Bone marrow was flushed and isolated using icecold PBS. Cells were then cultured in DMEM D5796 supplemented with 10\% FBS, 10\% M-CSF and 0.5\% Pen/ Strep. At day 5, adherent macrophages were collected by scraping, counted and seeded for experiment. LPS (from E.coli, Sigma L6529) was prepared as a working stock of $1 \mu \mathrm{g} / \mathrm{mL}$ in DMEM and spiked 1:100 into the wells of the culture dish for a final concentration of $10 \mathrm{ng} / \mathrm{mL}$. For cell counting and assessment of cell viability a $\mathrm{Vi}-\mathrm{Ce} \mathrm{ll}^{\mathrm{TM}}$ XR (Beckman Coulter) automated cell counter was used according to the manufacturer's instructions.

\section{Metabolite extraction from medium, derivatisation, and GC-MS measurement}

The method was adopted from [20] with the following changes: Extracellular metabolites from culture medium samples were extracted in triplicate using a methanol/water mixture $(5: 1, \mathrm{v} / \mathrm{v})$. The water fraction contained the internal standard (IS) Pentanedioic acid-D6 ( $c=10 \mu \mathrm{g} / \mathrm{mL} ; \mathrm{C} / \mathrm{D} / \mathrm{N}$ Isotopes Inc.). $40 \mu \mathrm{L}$ of medium were added to $240 \mu \mathrm{L}$ of the ice-cold methanol/water+IS mixture $(5: 1, \mathrm{v} / \mathrm{v})$. After adding $100 \mu \mathrm{L}$ ice-cold chloroform, the mixture was vortexed for $10 \mathrm{~min}$ at $4^{\circ} \mathrm{C}$ and 2,000 rpm (Eppendorf Thermomixer C). For phase separation, $100 \mu \mathrm{l}$ of chloroform and $100 \mu \mathrm{l}$ of water were added and vortexed for $1 \mathrm{~min}$ at $4^{\circ} \mathrm{C}$ and $2,000 \mathrm{rpm}$. Then, the mixture was centrifuged at $21,000 \times \mathrm{g}$ for $5 \mathrm{~min}$ at $4^{\circ} \mathrm{C} .250 \mu \mathrm{L}$ of the polar (upper) phase were transferred to GC glass vial with micro insert $(5-250 \mu \mathrm{L})$ and evaporated to dry under vacuum at $-4^{\circ} \mathrm{C}$.

For absolute metabolite quantification, a dilution series of IA was included in the extraction procedure and measured in triplicate. The stock solution $(c=20 \mathrm{mM})$ was freshly prepared by dissolving IA in water. It was used for the preparation of an external calibration curve in DMEM D5796 with $10 \%$ FBS medium with the following concentration levels: $0.01 ; 0.05 ; 0.1 ; 0.5 ; 1 ; 5 ; 10$ and $12.5 \mu \mathrm{M}$.

Metabolite derivatisation was performed by using a multipurpose sampler (Gerstel). Dried medium extracts were dissolved in $15 \mu \mathrm{L}$ pyridine, containing $20 \mathrm{mg} / \mathrm{ml}$ methoxyamine hydrochloride (Sigma-Aldrich), at $55^{\circ} \mathrm{C}$ for 90 min under shaking. After adding $15 \mu \mathrm{L}$ MTBSTFA +

\section{Correlation CRP vs IA}

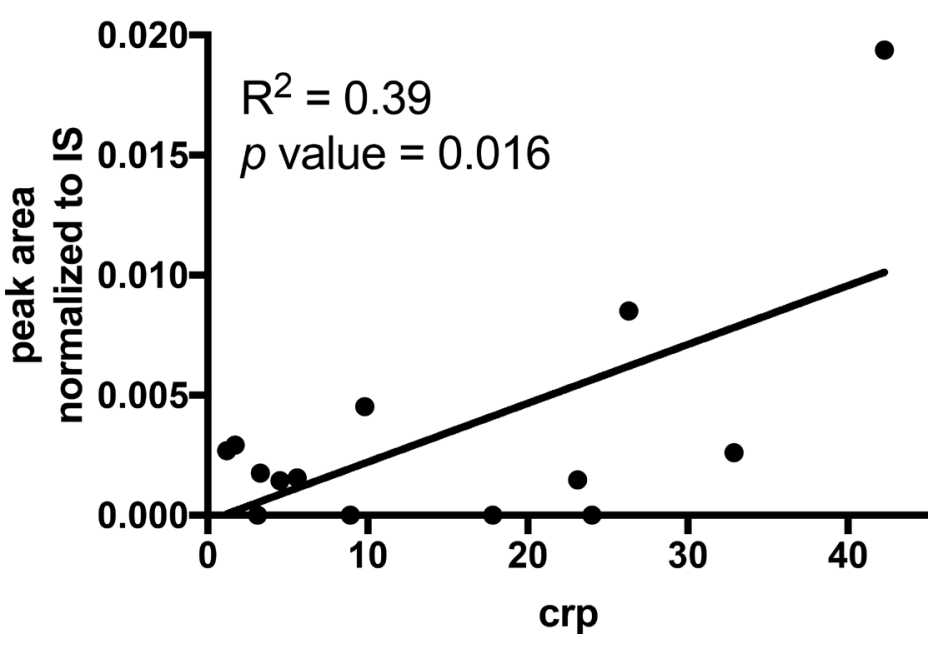

Figure 3: Correlation analysis of CRP and IA signals in cell pellets of BALF's. Each dot indicates one patient $(n=14)$. $p$ value was calculated using linear regression. 
Table 4: Overview commercially obtained blood samples of septic patients

\begin{tabular}{llcccc}
\hline Product ID & \multicolumn{1}{c}{ Matrix } & Age & Gender & Ethnicity & Type of Infection \\
\hline KH17_11267 & K2 EDTA Plasma & 86 & M & White & Beta-hemolytic streptococci group \\
KH17_11835 & K2 EDTA Plasma & 84 & F & White & G \\
KH17_12100 & K2 EDTA Plasma & 65 & F & White & E.coli \\
KH17_12101 & K2 EDTA Plasma & 69 & F & White & Klinfluebsiella pneumoniae \\
KH17_2738 & Serum & 82 & F & White & E.coli \\
KH17_4848 & Serum & 45 & M & White & Klebsiella pneumoniae \\
KHBR_0600 & Serum & 42 & M & Black & Staph haemolyticus \\
KH17_4596 & Serum & 53 & M & Black & Staph epidermidis \\
\hline
\end{tabular}

$1 \%$ TBDMSCI (Restek), samples were incubated at $55^{\circ} \mathrm{C}$ for 60 min under continuous shaking.

GC-MS analysis was performed by using an Agilent 7890A GC coupled to an Agilent 5975C inert XL Mass Selective Detector (Agilent Technologies). A sample volume of $1 \mu \mathrm{L}$ was injected into a Split/Splitless inlet, operating in split mode $(10: 1)$ at $270^{\circ} \mathrm{C}$. The gas chromatograph was equipped with a $30 \mathrm{~m}$ (I.D. $0.25 \mathrm{~mm}$, film $0.25 \mu \mathrm{m}$ ) DB-35MS capillary column (Agilent J\&W GC Column). Helium was used as the carrier gas with a constant flow rate of $1.4 \mathrm{~mL} / \mathrm{min}$. The $\mathrm{GC}$ oven temperature was held at $100^{\circ} \mathrm{C}$ for $1 \mathrm{~min}$ and increased to $200^{\circ} \mathrm{C}$ at $8^{\circ} \mathrm{C} / \mathrm{min}$. Then, the temperature was increased to $325^{\circ} \mathrm{C}$ at $50^{\circ} \mathrm{C} / \mathrm{min}$ and held for $6 \mathrm{~min}$. The total run time was $22 \mathrm{~min}$. The transfer line temperature was set to $280^{\circ} \mathrm{C}$. The MSD was operated under electron ionization at $70 \mathrm{eV}$. The MS source was held at $230^{\circ} \mathrm{C}$ and the quadrupole at $150^{\circ} \mathrm{C}$. For precise quantification, GC-MS measurements were performed in selected ion monitoring (SIM) mode using the following masses: $\mathrm{m} / \mathrm{z} 301.2 ; 343.2$; 358.2 (dwell times: $60 \mathrm{~ms}$ ) for itaconic acid and $\mathrm{m} / \mathrm{z}$ 235.2; 309.2; 351.3 (dwell times: $75 \mathrm{~ms}$ ) for Pentanedioic acid-D6.

\section{Metabolite extraction from plasma, serum and urine, derivatisation, and GC-MS measurement}

$200 \mu \mathrm{L}$ urine were centrifuged at $400 \times \mathrm{g}$ for $5 \mathrm{~min}$ at $4^{\circ} \mathrm{C} .100 \mu \mathrm{L}$ supernatant were mixed with $75 \mu \mathrm{L}$ urease $(5 \mathrm{mg} / \mathrm{mL}$ in HEPES, $c=25 \mathrm{mM}, \mathrm{pH}: 7,0)$. The mixture was kept for $5 \mathrm{~min}$ at $37^{\circ} \mathrm{C} .15 \mu \mathrm{L}$ were mixed with $135 \mu \mathrm{L}$ of methanol/water mixture $(8: 1, \mathrm{v} / \mathrm{v})$. The mixture was vortexed for $5 \mathrm{~min}$ at $4^{\circ} \mathrm{C}$ and 1,400 rpm (Eppendorf Thermomixer). Then, the mixture was centrifuged at $21,000 \times \mathrm{g}$ for $5 \mathrm{~min}$ at $4^{\circ} \mathrm{C} .30 \mu \mathrm{L}$ were transferred to a GC glass vial with micro insert $(5-250 \mu \mathrm{L})$ and evaporated to dry under vacuum at $-4^{\circ} \mathrm{C}$.

For plasma and serum extraction, $15 \mu \mathrm{L}$ of plasma or serum were mixed with $135 \mu \mathrm{L}$ of methanol/water mixture $(8: 1, \mathrm{v} / \mathrm{v})$ including internal standard Pentanedioic
acid-D6 ( $c=2 \mu \mathrm{g} / \mathrm{mL})$. Further processing was identical to the urine samples. For commercial sepsis samples, $60 \mu \mathrm{L}$ were transferred to a GC glass vial with micro insert and evaporated to dry under vacuum at $-4^{\circ} \mathrm{C}$.

Metabolite derivatisation was performed by using a multipurpose sampler (Gerstel). Dried medium extracts were dissolved in $15 \mu \mathrm{L}$ pyridine, containing $20 \mathrm{mg} / \mathrm{mL}$ methoxyamine hydrochloride (Sigma-Aldrich), at $40^{\circ} \mathrm{C}$ for 60 min under shaking. After adding $15 \mu \mathrm{L}$ MSTFA (Macherey-Nagel), samples were incubated at $40^{\circ} \mathrm{C}$ for 30 min under continuous shaking.

GC-MS analysis was performed by using an Agilent 7890A GC coupled to an Agilent 5975C inert XL Mass Selective Detector (Agilent Technologies). A sample volume of $1 \mu \mathrm{L}$ was injected into a Split/Splitless inlet, operating in splitless mode (plasma split mode 10:1) at $270^{\circ} \mathrm{C}$. The gas chromatograph was equipped with a $30 \mathrm{~m}$ (I.D. $250 \mu \mathrm{m}$, film $0.25 \mu \mathrm{m}$ ) DB-35MS capillary column (Agilent J\&W GC Column). Helium was used as the carrier gas with a constant flow rate of $1.2 \mathrm{~mL} / \mathrm{min}$. The GC oven temperature was held at $80^{\circ} \mathrm{C}$ for $1 \mathrm{~min}$ and increased to $320^{\circ} \mathrm{C}$ at $15^{\circ} \mathrm{C} / \mathrm{min}$ and held for $8 \mathrm{~min}$. The total run time was $25 \mathrm{~min}$. Plasma: $90^{\circ} \mathrm{C}$ for $1 \mathrm{~min}, 9^{\circ} \mathrm{C} / \mathrm{min}$ to $270^{\circ} \mathrm{C}, 25^{\circ} \mathrm{C} / \mathrm{min}$ to $320^{\circ} \mathrm{C}$. Held for $7 \mathrm{~min}$. The total run time was $30 \mathrm{~min}$. The transfer line temperature was set to $280^{\circ} \mathrm{C}$. The MSD was operated under electron ionization at $70 \mathrm{eV}$. The MS source was held at $230^{\circ} \mathrm{C}$ and the quadrupole at $150^{\circ} \mathrm{C}$. For precise quantification, GCMS measurements were performed in SIM mode using the following masses: $\mathrm{m} / \mathrm{z} 215.1$; 230.1; 259.1 (dwell times: $50 \mathrm{~ms}$ ) for Itaconic acid and $\mathrm{m} / \mathrm{z} 206.1 ; 239.1 ; 267.1$ (dwell times: $50 \mathrm{~ms}$ ) for Pentanedioic acid-D6.

\section{Metabolite extraction from bronchioalveolar lavage fluid (BALF), derivatisation, and GC-MS measurement}

For BALF extraction, $15 \mu \mathrm{L}$ of BALF were mixed with $135 \mu \mathrm{L}$ of methanol/water mixture $(8: 1$, $\mathrm{v} / \mathrm{v}$ ) including internal standard Pentanedioic acid-D6 
$(c=2 \mu \mathrm{g} / \mathrm{mL})$. The mixture was vortexed for $5 \mathrm{~min}$ at $4^{\circ} \mathrm{C}$ and 1,400 rpm (Eppendorf Thermomixer). Then, the mixture was centrifuged at $21,000 \times \mathrm{g}$ for $5 \mathrm{~min}$ at $4^{\circ} \mathrm{C}$. $60 \mu \mathrm{L}$ were transferred to a $\mathrm{GC}$ glass vial with micro insert and evaporated to dry under vacuum at $-4^{\circ} \mathrm{C}$.

Metabolite derivatisation was performed by using a multipurpose sampler (Gerstel). Dried medium extracts were dissolved in $15 \mu \mathrm{L}$ pyridine, containing $20 \mathrm{mg} / \mathrm{mL}$ methoxyamine hydrochloride (Sigma-Aldrich), at $55^{\circ} \mathrm{C}$ for 90 min under shaking. After adding $15 \mu \mathrm{L}$ MTBSTFA $+1 \%$ TBDMSC (Restek), samples were incubated at $55^{\circ} \mathrm{C}$ for 60 min under continuous shaking.

GC-MS analysis was performed by using an Agilent 7890A GC coupled to an Agilent 5975C inert XL Mass Selective Detector (Agilent Technologies). A sample volume of $1 \mu \mathrm{L}$ was injected into a Split/Splitless inlet, operating in splitless mode at $270^{\circ} \mathrm{C}$. The gas chromatograph was equipped with a $30 \mathrm{~m}$ (I.D. $0.25 \mathrm{~mm}$, film $0.25 \mu \mathrm{m}$ ) DB-35MS capillary column (Agilent $\mathrm{J} \& \mathrm{~W}$ GC Column). Helium was used as the carrier gas with a constant flow rate of $1.2 \mathrm{~mL} / \mathrm{min}$. The $\mathrm{GC}$ oven temperature was held at $100^{\circ} \mathrm{C}$ for $2 \mathrm{~min}$ and increased to $300^{\circ} \mathrm{C}$ at $10^{\circ} \mathrm{C} / \mathrm{min}$. Then, the temperature was held for $4 \mathrm{~min}$. The total run time was $26 \mathrm{~min}$. The transfer line temperature was set to $280^{\circ} \mathrm{C}$. The MSD was operated under electron ionization at $70 \mathrm{eV}$. The MS source was held at $230^{\circ} \mathrm{C}$ and the quadrupole at $150^{\circ} \mathrm{C}$. For precise quantification, GC-MS measurements were performed in selected ion monitoring (SIM) mode using the following masses: $m / z$ 301.2; 343.2; 358.2 (dwell times: $60 \mathrm{~ms}$ ) for Itaconic acid and $\mathrm{m} / \mathrm{z}$ 235.2; 309.2; 351.3 (dwell times: $75 \mathrm{~ms}$ ) for Pentanedioic acid-D6.

\section{Metabolite extraction and intracellular itaconic acid quantification from BMDMs}

Prior extraction, LPS-stimulated and non-stimulated BMDMs were washed with $0.9 \% \mathrm{NaCl}$. For intracellular metabolite extraction, $200 \mu \mathrm{L}$ of ice-cold methanol and $200 \mu \mathrm{L}$ of water containing $1 \mu \mathrm{g} / \mathrm{mL}$ Pentanedioic acid-D6 as internal standard were added and cells were scraped and transferred into a $1.5 \mathrm{~mL}$ reaction tube containing $200 \mu \mathrm{l}$ of chloroform. For intracellular Itaconic acid quantification by standard addition, aliquots of the water fraction (containing internal standard) were separately spiked with different concentrations of Itaconic acid (25; 50 and $100 \mu \mathrm{M})$ to extrapolate intracellular Itaconic acid levels. The mixtures were vortexed for $20 \mathrm{~min}$ at $4^{\circ} \mathrm{C}$ and $1,400 \mathrm{rpm}$ and centrifuged for $10 \mathrm{~min}$ at $4^{\circ} \mathrm{C}$ and $17,000 \times$ g. $200 \mu \mathrm{L}$ of the upper polar phase were transferred to a GC glass vial with micro insert and evaporated to dry under vacuum at $-4^{\circ} \mathrm{C}$. Derivatization and GC-MS measurement was performed as reported in section "Metabolite extraction from bronchioalveolar lavage fluid (BALF), derivatisation, and GC-MS measurement".

\section{Metabolite extraction from BALF cell pellets}

For metabolite extraction from cells present in BALF, $200 \mu \mathrm{l}$ ice-cold methanol, $200 \mu \mathrm{L}$ water containing $1 \mu \mathrm{g} / \mathrm{mL}$ Pentanedioic acid-D6 as internal standard and $200 \mu \mathrm{L}$ chloroform was added to the cell pellet and vortexed for $20 \mathrm{~min}$ at $4^{\circ} \mathrm{C}$ and $1,400 \mathrm{rpm}$. Then, the mixture was centrifuged for $10 \mathrm{~min}$ at $4^{\circ} \mathrm{C}$ and $17,000 \times \mathrm{g}$ and $250 \mu \mathrm{L}$ of the upper polar phase were transferred to a GC glass vial with micro insert. Extracts were dried under vacuum at $-4^{\circ} \mathrm{C}$. Derivatization and GC-MS measurement was performed as described in section "Metabolite extraction from bronchioalveolar lavage fluid (BALF), derivatisation, and GC-MS measurement".

\section{Data normalisation and data processing}

All GC-MS chromatograms were processed using MetaboliteDetector, v3.020151231Ra [21]. The software package supports automatic deconvolution of all mass spectra. Compounds were annotated by retention time and mass spectrum. The internal standard was added at the same concentration to every medium sample to correct for uncontrolled sample losses and analyte degradation during metabolite extraction. The data set was normalised by using the response ratio of the integrated peak area: analyte and the integrated peak area:_internal standard. Absolute concentrations were determined using the response ratios of the calibration curve of Itaconic acid as a function to quantify concentrations.

\section{Patient study}

The cohort study was approved by the ethics committee of the state of Saarland, Germany (230/11) as well as the state research ethics committee of Luxembourg (201203/07). Patients or legal guardian were informed and asked for consent before sampling took place. Plasma and urine samples were collected from patients that were hospitalised for sepsis. Diagnosis was based on chart information (fever, c-reactive protein elevation CRP, evidence of bacteria in bloodstream, antibiotic treatment). Sampling procedures were incorporated into routine blood, urine or bronchial lavage examinations to avoid any extra stress to the subjects. Clinical information was taken from the chart. Blood and urine samples were immediately processed as described above.

Commercial sepsis samples were purchased from Discovery Life Sciences (for sample details see Table 4). 


\section{Abbreviations}

CRP: C reactive protein; GC-MS: Gas Chromatography Mass Spectrometry; IA: Itaconic acid; Leu: Leukocytes; LPS: lipopolysaccharide; PCT: Procalcitonin; SDH: Succinate dehydrogenase; SIM: Selected Ion Monitoring.

\section{Author contributions}

JM, LK and CJ performed experiments, AL, HM, PML and JGS organised patient study and collected samples; KH and JGS supervised study; JM and JGS wrote the manuscript; all authors read and discussed the manuscript.

\section{ACKNOWLEDGMENTS}

The authors thank the patients that volunteered to contribute to this study.

\section{CONFLICTS OF INTEREST}

The authors declare no conflicts of interest.

\section{FUNDING}

JM was supported by the FNR (grant no. 3973022) and by a DFG Fellowship (no. ME 4636/2-1). KH was supported by the FNR with the ATTRACT program (A10/03). JGS was supported by CIG303682 and FNR CORE (Itgb3 VascIn).

\section{REFERENCES}

1. de Seymour JV, Conlon CA, Sulek K, Villas Boas SG, McCowan LM, Kenny LC, Baker PN. Early pregnancy metabolite profiling discovers a potential biomarker for the subsequent development of gestational diabetes mellitus. Acta Diabetol. 2014; 51:887-90. https://doi.org/10.1007/ s00592-014-0626-7.

2. Michelucci A, Cordes T, Ghelfi J, Pailot A, Reiling N, Goldmann O, Binz T, Wegner A, Tallam A, Rausell A, Buttini M, Linster CL, Medina E, et al. Immune-responsive gene 1 protein links metabolism to immunity by catalyzing itaconic acid production. Proc Natl Acad Sci U S A. 2013; 110:7820-5. https://doi.org/10.1073/pnas.1218599110.

3. Strelko CL, Lu W, Dufort FJ, Seyfried TN, Chiles TC, Rabinowitz JD, Roberts MF. Itaconic acid is a mammalian metabolite induced during macrophage activation. J Am Chem Soc. 2011; 133:16386-9. https://doi.org/10.1021/ ja2070889.

4. Naujoks J, Tabeling C, Dill BD, Hoffmann C, Brown AS, Kunze M, Kempa S, Peter A, Mollenkopf HJ, Dorhoi A,
Kershaw O, Gruber AD, Sander LE, et al. IFNs Modify the Proteome of Legionella-Containing Vacuoles and Restrict Infection Via IRG1-Derived Itaconic Acid. PLoS Pathog. 2016; 12:e1005408. https://doi.org/10.1371/journal. ppat.1005408.

5. Cordes T, Wallace M, Michelucci A, Divakaruni AS, Sapcariu SC, Sousa C, Koseki H, Cabrales P, Murphy AN, Hiller K, Metallo CM. Immunoresponsive Gene 1 and Itaconate Inhibit Succinate Dehydrogenase to Modulate Intracellular Succinate Levels. J Biol Chem. 2016; 291:14274-84. https://doi.org/10.1074/jbc.M115.685792.

6. Lampropoulou V, Sergushichev A, Bambouskova M, Nair S, Vincent EE, Loginicheva E, Cervantes-Barragan L, Ma X, Huang SC, Griss T, Weinheimer CJ, Khader S, Randolph GJ, et al. Itaconate Links Inhibition of Succinate Dehydrogenase with Macrophage Metabolic Remodeling and Regulation of Inflammation. Cell Metab. 2016; 24:15866. https://doi.org/10.1016/j.cmet.2016.06.004.

7. Sugimoto M, Sakagami H, Yokote Y, Onuma H, Kaneko M, Mori M, Sakaguchi Y, Soga T, Tomita M. Non-targeted metabolite profiling in activated macrophage secretion. Metabolomics. 2012; 8:624-33. https://doi.org/10.1007/ s11306-011-0353-9.

8. Lamprecht I, Schaarschmidt B, Welge G. Microcalorimetric investigation of the metabolism of yeasts. V. Influence of ploidy on growth and metabolism. Radiat Environ Biophys. 1976; 13:57-61.

9. Luan HH, Medzhitov R. Food Fight: Role of Itaconate and Other Metabolites in Antimicrobial Defense. Cell Metab. 2016; 24:379-87. https://doi.org/10.1016/j.cmet.2016.08.013.

10. Van den Bruel A, Thompson MJ, Haj-Hassan T, Stevens R, Moll H, Lakhanpaul M, Mant D. Diagnostic value of laboratory tests in identifying serious infections in febrile children: systematic review. BMJ. 2011; 342:d3082. https://doi.org/10.1136/bmj.d3082.

11. Abraham E. New Definitions for Sepsis and Septic Shock: Continuing Evolution but With Much Still to Be Done. JAMA. 2016; 315:757-9. https://doi.org/10.1001/ jama.2016.0290.

12. DiNardo CD, Propert KJ, Loren AW, Paietta E, Sun Z, Levine RL, Straley KS, Yen K, Patel JP, Agresta S, Abdel-Wahab O, Perl AE, Litzow MR, et al. Serum 2-hydroxyglutarate levels predict isocitrate dehydrogenase mutations and clinical outcome in acute myeloid leukemia. Blood. 2013; 121:4917-24.

13. Borger DR, Goyal L, Yau T, Poon RT, Ancukiewicz M, Deshpande V, Christiani DC, Liebman HM, Yang H, Kim H, Yen K, Faris JE, Iafrate AJ, et al. Circulating oncometabolite 2-hydroxyglutarate is a potential surrogate biomarker in patients with isocitrate dehydrogenase-mutant intrahepatic cholangiocarcinoma. Clin Cancer Res. 2014; 20:1884-90. https://doi.org/10.1158/1078-0432.CCR-13-2649.

14. Schuetz P, Mueller B. Procalcitonin: An Effective Screening Tool and Safe Therapeutic Decisionmaking Aid for Emergency Department Patients With Suspected Sepsis. 
Ann Emerg Med. 2015; 66:318-9. https://doi.org/10.1016/j. annemergmed.2015.03.029.

15. Michopoulos F, Karagianni N, Whalley NM, Firth MA, Nikolaou C, Wilson ID, Critchlow SE, Kollias G, Theodoridis GA. Targeted Metabolic Profiling of the Tg197 Mouse Model Reveals Itaconic Acid as a Marker of Rheumatoid Arthritis. J Proteome Res. 2016; 15:4579-4590. https://doi.org/10.1021/acs.jproteome.6b00654.

16. Meiser J, Kramer L, Sapcariu SC, Battello N, Ghelfi J, D'Herouel AF, Skupin A, Hiller K. Pro-inflammatory Macrophages Sustain Pyruvate Oxidation through Pyruvate Dehydrogenase for the Synthesis of Itaconate and to Enable Cytokine Expression. J Biol Chem. 2016; 291:3932-46. https://doi.org/10.1074/jbc.M115.676817.

17. Wang SF, Adler J, Lardy HA. The pathway of itaconate metabolism by liver mitochondria. J Biol Chem. 1961; 236:26-30.

18. Adler J, Wang SF, Lardy HA. The metabolism of itaconic acid by liver mitochondria. J Biol Chem. 1957; 229:865-79.
19. Ko SH, Choi GE, Oh JY, Lee HJ, Kim JS, Chae CW, Choi D, Han HJ. Succinate promotes stem cell migration through the GPR91-dependent regulation of DRP1mediated mitochondrial fission. Sci Rep. 2017; 7:12582. https://doi.org/10.1038/s41598-017-12692-x.

20. Hillje AL, Beckmann E, Pavlou MA, Jaeger C, Pacheco MP, Sauter T, Schwamborn JC, Lewejohann L. The neural stem cell fate determinant TRIM32 regulates complex behavioral traits. Front Cell Neurosci. 2015; 9:75. https:// doi.org/10.3389/fncel.2015.00075.

21. Hiller K, Hangebrauk J, Jager C, Spura J, Schreiber K, Schomburg D. MetaboliteDetector: comprehensive analysis tool for targeted and nontargeted GC/MS based metabolome analysis. Anal Chem. 2009; 81:3429-39. https://doi. org/10.1021/ac802689c. 